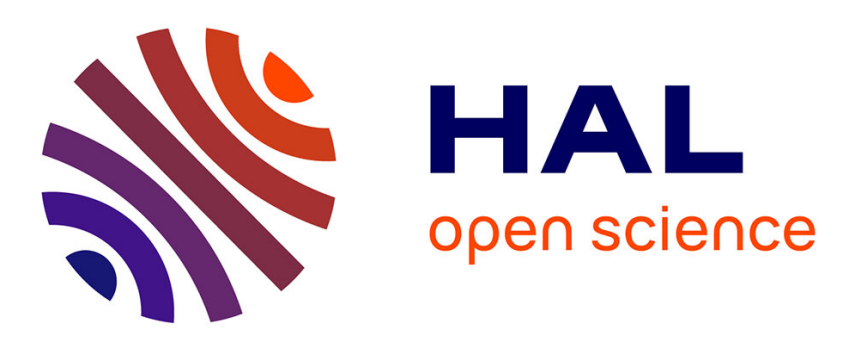

\title{
Standardization of Ceramic Assemblages: Transmission Mechanisms and Diffusion of Morpho-Functional Traits across Social Boundaries
}

\author{
Valentine Roux
}

\section{- To cite this version:}

Valentine Roux. Standardization of Ceramic Assemblages: Transmission Mechanisms and Diffusion of Morpho-Functional Traits across Social Boundaries. Journal of Anthropological Archaeology, 2015, 40, pp.1-9. 10.1016/j.jaa.2015.04.004 . hal-01548565

\section{HAL Id: hal-01548565 \\ https://hal.parisnanterre.fr/hal-01548565}

Submitted on 25 Jun 2018

HAL is a multi-disciplinary open access archive for the deposit and dissemination of scientific research documents, whether they are published or not. The documents may come from teaching and research institutions in France or abroad, or from public or private research centers.
L'archive ouverte pluridisciplinaire HAL, est destinée au dépôt et à la diffusion de documents scientifiques de niveau recherche, publiés ou non, émanant des établissements d'enseignement et de recherche français ou étrangers, des laboratoires publics ou privés. 


\title{
Standardization of ceramic assemblages: Transmission mechanisms and diffusion of morpho- functional traits across social boundaries
}

\author{
Valentine Roux \\ CNRS - Université de Paris Ouest Nanterre La Défense, Maison de l'Archéologie et de l'Ethnologie, 21 allée de l'université, 92023 Nanterre cedex, France \\ E-mail address: valentine.roux@mae.u-paris10.fr \\ http://dx.doi.org/10.1016/j.jaa.2015.04.004
}

\begin{abstract}
This paper addresses the question of the diffusion of morpho-functional traits across social boundaries. A present-day situation is examined. It describes the widespread adoption of a granite tempered water jar by two social communities of potters who used to produce distinct ranges of morpho-functional vessels. The analysis of the transmission mechanisms shows that diffusion of such traits occurred both through indirect and direct transmission. Indirect transmission occurred at the inter-group level while direct transmission under the form of technical guidance occurred at the intra-group level. These were triggered by the intention of the artisans to produce a model valued by the consumers and which sells well. This intention took place in a context of collapse of the previous economic system. These results suggest that in a context where ceramic production was previously diversified and economically complementary, the standardization of morpho-functional traits signals that an established «rule» was transgressed and therefore that major socio-economic changes took place.
\end{abstract}

Keywords: Standardization, Diffusion, Pottery, India, Ethno-archaeology, Transmission, Social boundary

It is well recognized that material culture defines cultural boundaries whose relationship with social identities may, however, be difficult to establish, given that these boundaries fluctuate through a recurrent process of homogenization and fragmentation taking place at different space and time scales (Brubaker and Cooper, 2000; Gosselain, 2010a, 2011). Fragmentation and resistance to a general homogenizing process has been explored within different theoretical frameworks (Stark et al., 2008). Accordingly, it has been explained either in terms of group identity through affiliation dynamics and social distinction (Bowser, 2005, 2000; Degoy, 2008; Dietler and Herbich, 1998; Gosselain, 2000; Hegmon, 1998 ; Hodder, 1985; Lave and Wenger, 1991; Lemonnier, 2004, 1993; Stark, 1998), or in terms of adaptive advantages (Henrich and Boyd, 1998; McElreath et al., 2003; Richerson and Boyd, 2005; Shennan, 2002).

The homogenizing process raises the question of the transgression of the social borders established through affiliation and social distinction and experienced in daily life through the practice of a craft activity (Lave and Wenger, 1991). In archaeology, this transgression is explained in terms of either demic or cultural diffusion. The latter implies copying mechanisms, also called social learning strategies, which are described as either content dependent (adoption of a trait because it is considered superior to the other), or context dependent (adoption of a trait owing to its social or frequency context) (Boyd and Richerson, 1985; Henrich and McElreath, 2003; Mesoudi, 2013; O'Brien and Bentley, 2011; Shennan, 2008). These copying mechanisms describe at the micro-level how traits may be copied and so how assemblages may become uniform.

However, many questions are still pending, on the one hand concerning the modes of transmission by which these copying mechanisms are implemented (direct or indirect transmission through movements of individuals, objects or ideas) depending on the nature of the trait (Gosselain, 2000; Sigaut, 1999); on the other hand concerning the conditions under which these modes of transmission and related copying mechanisms are triggered and can lead to the transgression of cultural boundaries. The hypothesis is that these conditions may correspond to regularities (Gallay, 2011; Roux, 2007), providing thus interpretative models for explaining large-scale historical dynamics responsible for the standardization of assemblages over large areas as evidenced, for example, by the oriental ceramic assemblages of the 2nd millennium BC (examples in Glatz, 2015).

This paper addresses these questions by providing new empirical data on the diffusion of morpho-functional traits between two social communities who once used to produce distinct ranges of vessels. In a first section, I describe the process through which the same type of jar characterized by both a specific clay recipe and vessel shape came to be adopted by all the artisans and distributed on a very large-scale area. Artisans belong to two distinct social groups both of which are specialized and work at the domestic scale. They are settled in the Jodhpur region (Rajasthan, India), scattered over an area of roughly $40000 \mathrm{~km}^{2}$. The water jars are distributed in both Rajasthan and Gujarat over an area of more than $140000 \mathrm{~km}^{2}$. In a second section I examine the context of diffusion, i.e. the context in which the social border between the two communities became "porous". In a third part, I discuss the generality of the results obtained.

Let us specify that standardization, affecting either clay paste, composition of ceramic assemblages or metric dimensions, is most often studied to assess different types of specialization (Arnold, 2000, p. 200; Arnold and Nieves, 1992; Benco, 1988; Costin, 2001; Costin and Hagstrum, 1995; Kvamme et al., 1996; London, 1991; Longacre, 1999; Rice, 1991; Roux, 2003; Stark, 1995). This paper examines the standardization of ceramic assemblages (clay material and vessel shapes), but not in relation to craft specialization. Numerous examples are reported of craft specialists occupying the same geographical area and producing at a time t diverse ceramic assemblages (characterized by different ensembles of morpho-functional types) and, at a time $t+1$ or 1 , uniform assemblages (characterized by same morpho-functional types). This process through which a diversified production becomes uniform is examined here.

\section{Data and method}

The region under study is the Jodhpur region. It includes mainly the districts of Jodhpur and Barmer. It is inhabited by two endogamous communities of potters: the Moila Kumhar who are Muslims and the Prajapat Kumhar who are Hindu. They live apart in different villages, or in the same villages (ex. Mokalsar, Siwana, Pachpadra, Banar, Fig. 1). 


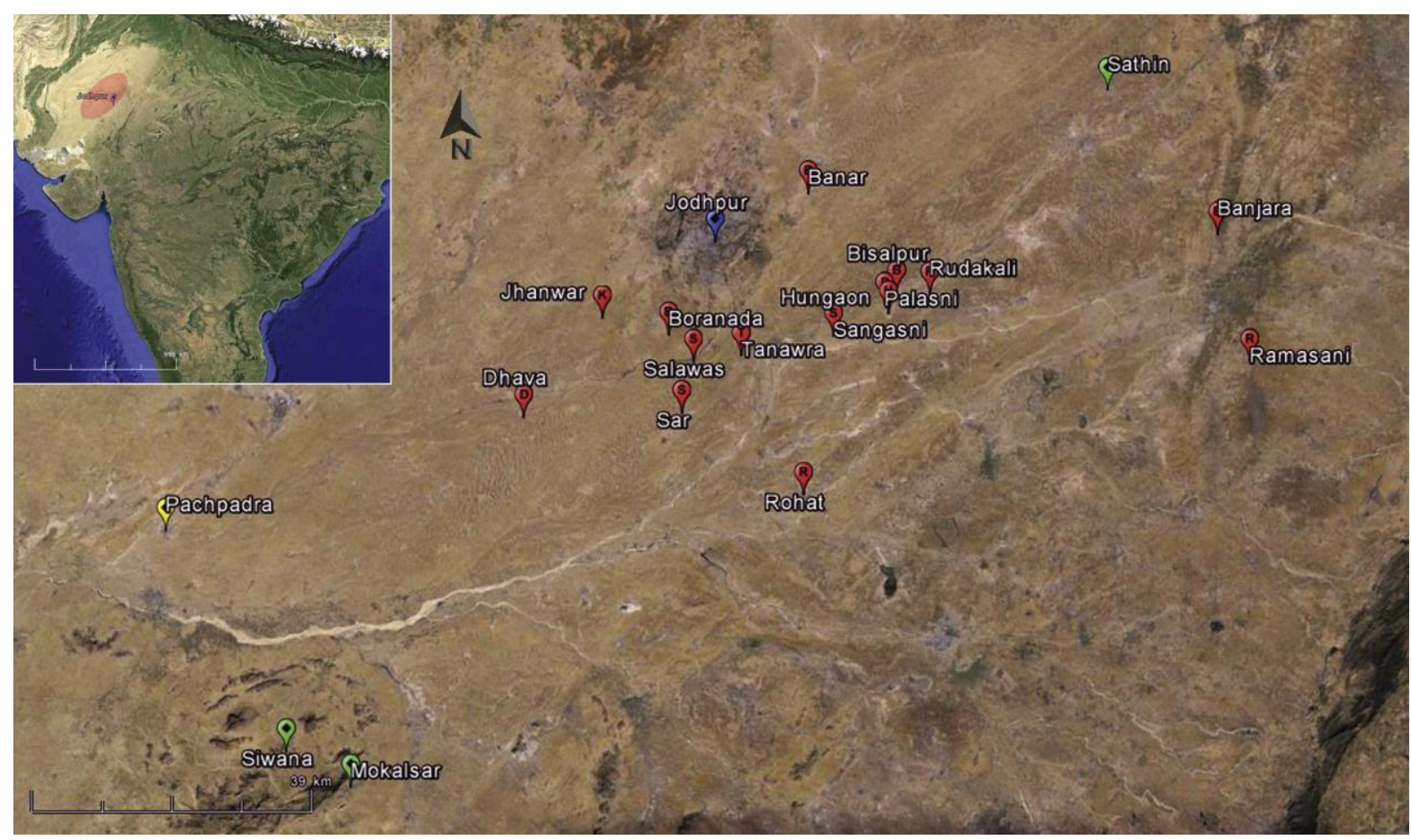

Fig. 1. Location of the villages surveyed.

The Moila potters of the Jodhpur and Barmer districts fall in 40 villages and 354 households. All the Moila potters entertain family relationships with matrimonial alliances within the Jodhpur region. The Prajapat potters of the Jodhpur and Barmer districts are few in numbers. They represent $10 \%$ of the Prajapat practicing 30 years ago. They live in rural production centers - Pachpadra and Sathin -, urban production center - Jodhpur city - and isolated villages. None of the Hindu potters distributed between the villages and the centers entertain family or professional relationships with each other.

We surveyed 15 Moila villages accounting for 259 households, 8 of them comprising more than 10 households (Banar, Banjara, Boranada Basni, Ramasani, Rudakali, Salawas, Sangasni, Sar). We surveyed three Hindu rural centers - Pachpadra with 40 potters' households, Mokalsar with 12 potters' households and Sathin with 5 potters' households -, three Hindu isolated villages with one to three households (Palasni, Bisalpur, Hungaon), and Jodhpur city with 5 Hindu potters' households (Fig. 1).

Up to 30 years ago, Prajapat and Moila Kumhar used to manufacture distinct ranges of ceramic vessels, the former being specialized in storage and transfer jars and the latter in "kitchen ware". They were not in competition; they were complementary, distributing their pots through different social and economic networks. The Prajapat Kumhar used to exchange their ceramic production against cereals within the jajmani system. This system was well known in traditional India. Potters had to provide client families with specific vessel types at particular times of the year (e.g., birth, betrothal, marriage, and death). In exchange, they received a portion of their client's crops. Their revenues were complemented by other professional occupations (often agricultural labor) as well as by distributing their production within economic networks through direct (in the case of rural centers or villages) or indirect sales (in the case of rural or urban centers). The Moila Kumhar used to sell "kitchen ware" through economic channels, either directly to the peasants (Hindu and Muslims), or indirectly to Jodhpuri shopkeepers or middlemen. They were important suppliers to Jodhpur, the main city of this area, the Hindu potters of Jodhpur not making the utilitarian vessels consumed by the urban population, i.e. mainly churns, cooking pots and dough troughs.

Both jars and kitchen ware were made out of local red clay, thrown on the wheel, paddled and painted. The technical differences between the two communities were to be found in the instruments: different types of fly wheel, paddling tools and open firings.

Nowadays, ceramic production of the two communities includes mainly white water jars made out of salty clay and tempered with sawdust and granite (Fig. 2). The shape is standardized. The body is globular and the neck is short with a grooved lip (Fig. 3). No painting is applied. There are three sizes of jar: small (less than 10 1), middle (15-20 1) and big (over 301 ). 

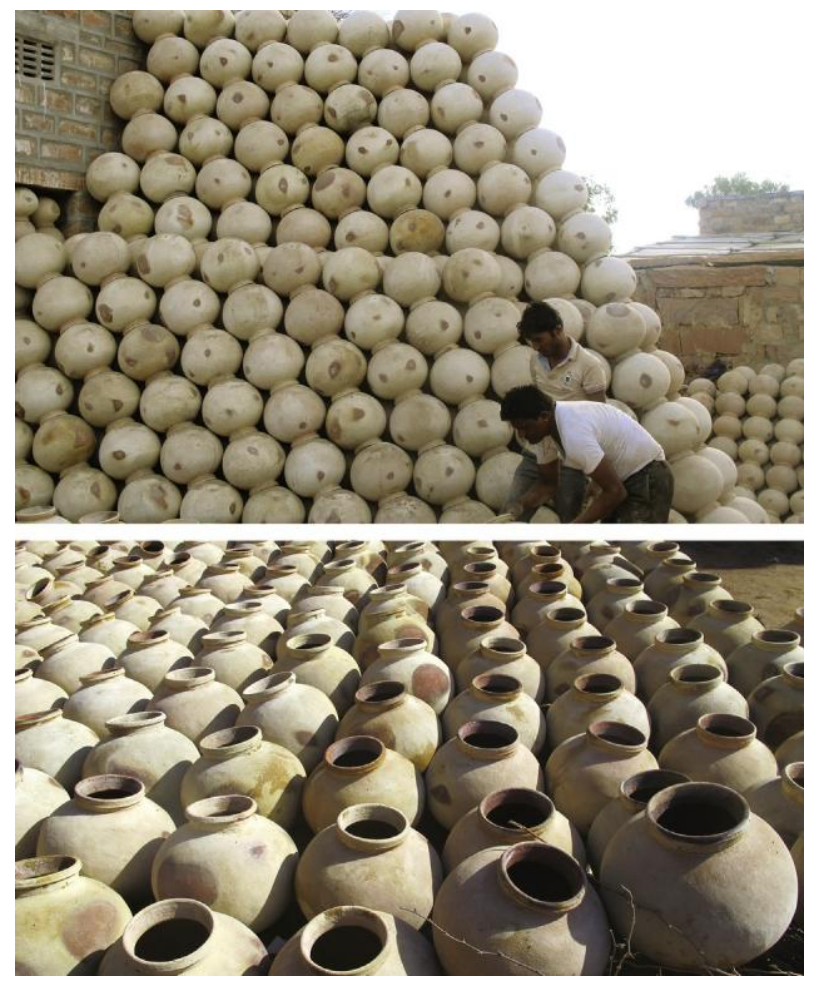

Fig. 2. Mass production of “Mokalsar”' jars. Above: Moila production (Salawas); Below: Prajapat production (Mokalsar).

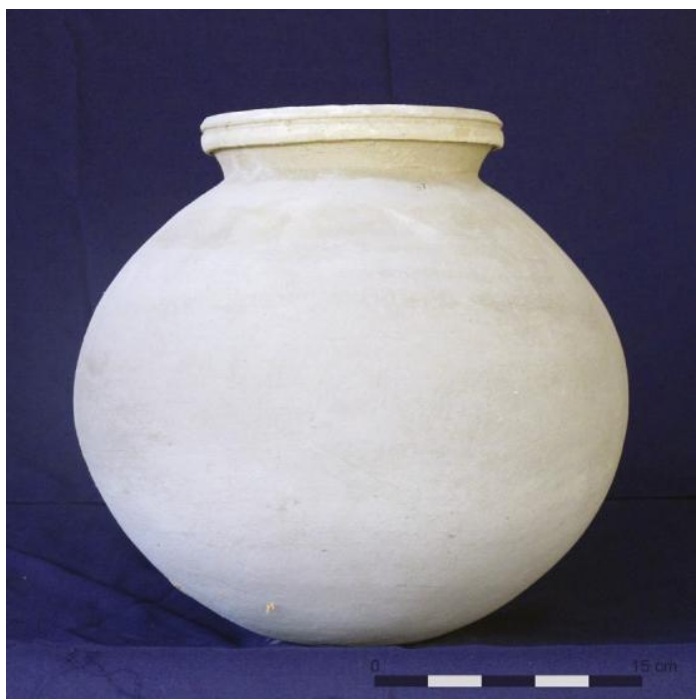

Fig. 3. The granite tempered white jar. The shape is standardized. It is characterized by a globular body, a short neck and a grooved lip.

The history of the diffusion of the white water jar is a recent one since it started only 30 years ago. It has been recorded on the basis of qualitative interviews conducted in the various villages surveyed. The potters were asked to recall the dates and the circumstances under which they started to manufacture this type of vessel. They were mainly potters around 60 years old. Memory was not vivid for all of them, but in each village there were always 2-3 potters who were able to report quite precisely about the way they had started to make white water jars. All in all, the history of the white water jar could be recorded in 16 villages. Records for the ceramic production in 1980 in the Jodhpur area were completed with Kramer's book (Kramer, 1997) which is a valuable source for quantitative data.

\section{The history of the diffusion of the white water jar}


The history of the diffusion of the white water jar includes two main steps: a first step during which potters started to make white jars similar to the ones from the rural center Pachapdra, and a second step during which potters made white jars similar to the ones from the town Mokalsar

\subsection{The history of the diffusion of the "Pachpadra" water jar}

In the seventies, the most renowned rural center for pottery manufacture was Pachpadra. Over there, Hindu potters used to make white water jars from salty clay. The fame of these water jars came from their water-cooling properties. As a general principle the porous clay pastes allow water to cool down: when water inside a pot is colder than the outside temperature, if it can permeate by capillarity to the outer surface, then evapo-transpiration occurs and diminishes the calorific capacities of the water, providing cool drinking water. The Pachpadra water jars were efficiently porous thanks to their clay paste made out of salty clay and donkey dung. Both components favor voids, the former by flocculation, the latter by burning when fired: donkey dung was pounded with a wooden club and sieved to recover the fine chopped straw that donkeys do not digest and that burnt when fired.

The fame of the Pachpadra water jars can be estimated against the number of vessels sold in 1980 in the shops of Jodhpur: 12151 out of 24253 (Kramer, 1997 , p. 137) which means that half of the vessels sold in Jodhpur originated from Pachpadra. Most of these vessels were water jars knowing that water jars are renewed each spring before the hot summer and that everybody (inhabitants, shopkeepers, food stalls, restaurants) wanted to have a "Pachpadra jar" for the sake of its cooling properties. This name is still famous and associated with all the white water jars even though they are not manufactured only in Pachpadra anymore. Aside from the Pachpadra water jars, the Pachpadra potters used to make red clay utilitarian utensils like pitchers, bowls, stands, storage jars, ritual vessels or flower pots.

Up to the end of the sixties beginning of the seventies, only the Pachpadra potters were making white water jars. However, in the beginning of the seventies, consumption of earthenware started to decrease dramatically. Plastic and metal objects invaded the lives of peasants who did not need any more pottery vessels and therefore started to diminish considerably their demand along with the annual quantity of cereals given to the Hindu potters. As a direct consequence of this technoeconomic situation Hindu potters started to shift from pottery to other professional occupations, massively quitting the profession within 20 years. In parallel, the Moila Kumhar started to take over the manufacture of the water jars, the type of vessel which hitherto had been the monopoly of the Hindu potters. However, they did not make the traditional local types of jar. They started to make "Pachpadra" water jars. The process by which the Moila gradually started to make water jars took 20 years, by which time $75 \%$ of the Hindu potters had left the profession, no longer meeting the demand for water jars. This process was directed by middlemen who explicitly asked the Moila to make white water jars, the type of jar which sold best and which originated from Pachpadra. The Moila potters acceded to their request by collecting salty clay in Rohat, a place $50 \mathrm{~km}$ away from Jodhpur where Moila had discovered that there were salty clay sources. The use of donkey dung as temper was not a problem, since Moila were already using it. As far as the shape was concerned, Pachpadra jars were available in the Jodhpur markets and therefore it was easy to copy them.

Bike Khan, a Moila potter from Sar, recalls the following story:

"I was 10 years old (1963) when middlemen came to my home asking my father to make white matka (jar). For this purpose we had to collect the clay from Rohat (dist. Jodhpur). Moila potters from Rohat had found that salty clay was available and appropriate for making white matka. This salty clay was free. At that time our ceramic production included both red clay vessels (with clay coming from the local tank) and white matka (in small proportions) which were in competition on the market with the red clay matka made by the local Hindu potters."

At that time, only a few Moila potters started to make white water jars. According to our interviews they were rare. The kitchenware production was still very much in demand. More of them started in the early seventies like Abdul Gani, a Moila potter from Banar, who says: "I changed clay in 1972 in order to make white matka when I saw their success in the market'. The clay was from Rohat. Kramer confirms these dates when she notes that some Muslim potters had begun to make matka in the seventies given the decline in the number of Hindu urban potters in Jodhpur city (Kramer, 1997, p. 228, note 17).

Unlike the Moila potters, the Hindu potters living in small scattered villages or gathered in rural production centers (ex. Sathin) and distributing their pots locally either through the jajmani system or through sales kept up their traditional production and did not make white matka.

\subsection{The history of the "Mokalsar"' water jar}

The real shift came in the late eighties when the Hindu potters quit massively pottery and the kitchenware fell into desuetude while the demand for water jars was still there. But the demand changed. It was not any more for "Pachpadra jars", but for "Mokalsar jars". The latter are granite tempered salty clay jars and called by the local population "bajri matka" ("granite jar"). This demand was directed by the middlemen as well as by the shopkeepers from Jodhpur city.

The so-called "Mokalsar water jar" was and is still in high demand because of its cooling properties. It is considered the most effective type of jar for cooling water. The clay paste is made out of salty clay, sawdust and granite. The sawdust, like donkey dung, creates voids when burnt during firing while the granite increases the capillarity of the clay walls given its porous properties. The proportion between salty clay/sawdust and granite is $4 / 1 / 1$. A good Mokalsar water jar is one which is very white and with "bubbled grit": it shows on the one hand a very good firing (when it is not fired enough, the clay paste is slightly pink), on the other hand, a good capillarity because of the melted granite.

As indicated by its name, the "Mokalsar jar" originates from Mokalsar, a small town located south of Pachapadra in Barmer district, around $150 \mathrm{~km}$ from Jodhpur (Fig. 1). It is known for its granite quarries. It is inhabited by Prajapat and Moila potters. The Prajapat were there before the Moila. They were specialized in the making of three size jars (small, middle, big). The clay paste recipe is said to be "traditional", except for the sawdust which replaced donkey dung in the nineties. The morphological features - a short neck with a grooved lip - are also said to be "traditional". Aside from these jars, potters used to make tiles with red clay. When the Moila potters settled in Mokalsar, they were first specialized in kitchen ware. They started to make white jars 35 years ago (1978), but in small quantities. It was only 20 years ago (1993), when the demand increased and the number of Hindu potters declined, that they increased their production. The Mokalsar jars were sold mainly south of Mokalsar towards Gujarat. Jodhpur city received very few of them. Thus, in 1980, only one specimen had been recorded by Kramer (out of 24253, Kramer, 1997, p. 137). The Mokalsar jars came in high demand in Jodhpur and all over the region within the next ten years. In response to this demand Mokalsar potters sold both to southern and Jodhpur regions. However, the Jodhpur market became saturated by the mid-nineties. Nowadays, Mokalsar potters keep distributing their production mainly southwards - in the Jalor district and in Gujarat.

The Mokalsar jars are highly recognizable because of the granite visible in the form of black grits scattered on the white clay walls. They are said to keep the water cooler than the Pachapadra jars thanks to the granite. As such, they rapidly became more appreciated than the traditional white water jars. In the light of an ever more pressing demand by customers, the shopkeepers ordered them expressly directly from the potters or from the middlemen. 
Different narratives report on the way potters were asked to make "Mokalsar jars" and how they started to make them.

Bike Khan, from Sar, recalls the following story: "Middlemen came to see my father to ask him to make Mokalsar jars. My father went to Mokalsar a few times. I went along with him when I was 20 years old (1973). The granite was free at that time. My father started to make Mokalsar jars by using the granite from Mokalsar and the white clay from Rohat. He said then to the potters from family related villages (Salawas, Sangasni, etc.) that the granite was coming from Mokalsar and that adding granite made the jars cooler. The shopkeepers wanted more and more of these jars. This is this way that the Mokalsar jars came to be manufactured by all the potters of the Jodhpur region",

In this narrative Bikhe Khan says that the Mokalsar jars started to be made by the beginning of the seventies. However, from Kramer's study one knows that hardly any Mokalsar jars were on sale in Jodhpur city in 1980. When asking potters the time period at which they started to make Mokalsar jar, it appears that most of them started to make Mokalsar water jars exclusively by the beginning of the nineties only, the peak being the mid-nineties (Fig. 1). This is also the time at which the Mokalsar potters stopped selling in Jodhpur because the market had become saturated.

Different narratives confirm that the manufacture of the Mokalsar jar started in the Jodhpur area mainly in the late eighties, early nineties. These narratives explain also how they came to know how to make them.

Sattar Khan, a Moila potter from Salawas, remembers: 'I've been making white jars for 30 years (1983) now. However, I started to put granite in them only 5 years later, in 1988, when the Mokalsar jars started to come in demand".

Abdul Gani, a Moila potter from Banar, recalls: "in 1992, we saw on the market of Jodhpur that the Mokalsar jars were selling better than the so-called Pachpadra jars because they kept the water cooler. We asked a middleman where to get the granite. He explained to us. We rented a truck and the six of us went to Mokalsar, met the company indicated by the middlemen (did not meet any local potters), filled up the truck, came back to Banar, and shared the granite between the different Moila potter households. This way all the Moila households adopted the Mokalsar jar at the same time. As far as the shape is concerned, when we were making "Pachpadra jars", the lip was flat and painted; when we started to make Mokalsar jars, in order to keep up with the model, we shifted from flat lips to grooved lips, the one made by the potters from Mokalsar. This way, customers thought that our jars were genuine Mokalsar jars".

Another Moila potter, from Salawas, Fakir, recalls: "20 years ago, in 1992, I was in the Jodhpur market and I met Mokalsar Hindu potters who were there to sell their water jars. They explained to me that they were mixing their clay with sawdust and granite. They were not reluctant to give their recipe because they were not selling much in Jodhpur and more and more Hindu potters were quitting the job. I decided then that I would start to make such jars".

Lastly, let us report a narrative from the village Banjara inhabited by Moila potters. This narrative explains how a whole village shifted from a traditional diversified production to a new uniform production including exclusively Mokalsar jars.

Babu remembers: "By the end of the eighties, beginning of the nineties, demand for kitchenware began to significantly decline, replaced by metal. Following a suggestion from my brother-in-law, Sattar Khan, in 1991-1992 I went to Salawas to train for 4-6 months with him in order to learn how to make Mokalsar matka and start a new ceramic production. I had to get trained to make them because the manufacture process for making large matka is different from that for making kitchenware. When I came back to Banjara, I explained to everybody. The production of Mokalsar matka arose especially as an economic solution because middlemen were placing the orders and distributing them, thus discharging us from direct sales. A few inhabitants tried to make Mokalsar jars by mixing local clay with salt. The clay became white but cracked. Others tried to mix granite with local clay but it did not work out. They then had to keep up with the Mokalsar recipe, that is Mokalsar salty clay and granite."

The manufacture of Mokalsar jars was adopted not only by the Moila potters, but also by the Prajapat potters from places other than Mokalsar. Indeed, even the Hindu potters who used to make red clay water jars shifted to the Mokalsar jar in order to meet the customers' demand.

The Pachpadra potters were the first Hindu potters who shifted in the eighties from white jars to granite tempered white jars. They used to sell their jars to Jodhpur up to the mid-nineties. When the market got saturated because of the increasing production of Mokalsar jars by the Moila potters, they started to sell mostly southwards in Barmer district and Gujarat.

The Hindu potters from other rural centers or villages came to adopt the "bajri matka" later. A narrative by a Hindu potter from Sathin, a previous center for the manufacture of storage jars, is a good example of the process according to which the Hindu rural community came also to make Mokalsar jars:

"Fifteen years ago (1998), Moila potters from neighboring villages (Rudakali, Bandera, Ramasani) started to sell in Sathin their Mokalsar jars. Gradually consumers were diverted from the red clay jars we used to make. As a consequence, seven years ago (2006), we decided to make Mokalsar jars ourselves. We went to Jodhpur city to find out how these jars were made. The shopkeepers told us that there were made with granite from Mokalsar. Four of us went then to Mokalsar and brought back granite. We tried to make the jars, but they were not really white. We went back to Mokalsar and ordered Mokalsar clay. But we fired the jars in open firings and the ones at the periphery were not well fired. We went back to Mokalsar and we watched how jars were fired in a kiln. Then we tried to make kilns. After many trials and errors, we succeeded and nowadays we are selling our Mokalsar jars in our area"

Another example is given by Palasni, a village with three Hindu households. Zori Lal recalls: "I started the bajri matka 15 years ago (1998). It was my retailer from Jodhpur who asked me to make bajri matka, saying that I will increase my revenues. He told me to put Mokalsar granite in my clay. I tried with my local clay. But the granite did not stand out and therefore was not visible for the customers. I then went to Mokalsar and fetched the clay. Nowadays, I make only bajri matka". 


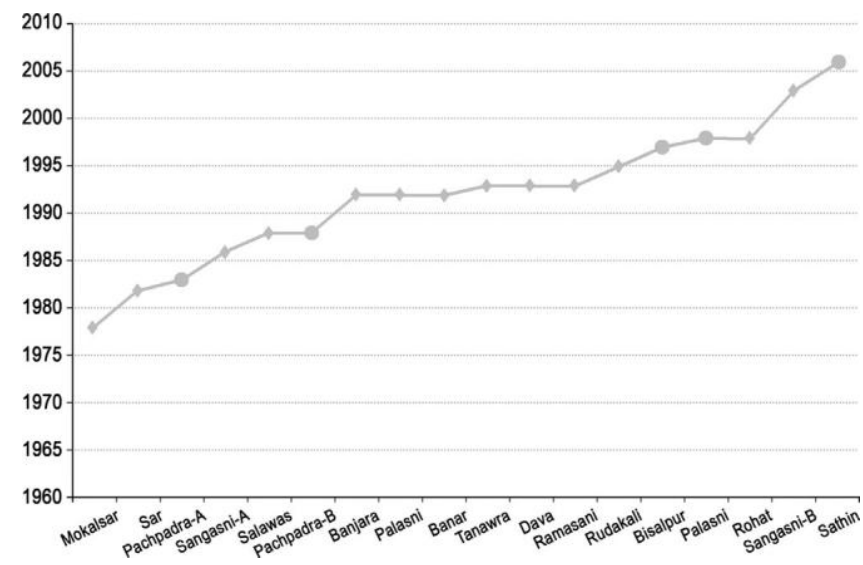

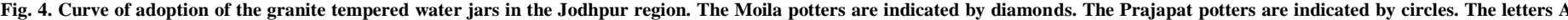
and $B$ associated to the names of the villages indicate different dates of adoption of the granite tempered water jar within a same village.

Nowadays, both Hindu and Muslim potters make Mokalsar jars. The Hindu potters represent only $10 \%$ of the active population from the seventies while the Muslim ones represent $85 \%$ of them. The curve of adoption of the Mokalsar jar in the Jodhpur region is given in Fig. 4.

\subsection{The Mokalsar clay paste}

The general adoption of the Mokalsar jar is not only the adoption of a shape, but also the adoption of a clay paste made up of salty clay, granite and sawdust.

The sawdust is a substitute for the previously used donkey dung. Donkey dung was used as temper by both communities, Moila and Prajapat. It was mixed with the local clay in order to make the various vessels, jars or kitchen ware. Proportions were the same as for saw dust (4 volumes of clay for one volume of donkey dung). Only the cooking pots had a different clay preparation. Two clods of clay were prepared, one out of local sandy clay not tempered, the other out of clay tempered with donkey dung. The two clods were then put on top of each other (the tempered clod above) and thrown on the wheel. The clay composition of the bottom of the cooking pot (without donkey dung) was meant to resist the repeated thermal shocks better. The preparation of the donkey dung was a tedious process since it had to be pounded and sieved. The saw dust came into use in the late eighties with free access to the sawmills in full development. It was rapidly adopted, saving time and effort compared to the donkey dung.

Salty clays are found in three locations: Mokalsar (Raithal source), Pachpadra (Khed source located a dozen km away) and Rohat (50 km from Jodhpur city). Granite is found in Mokalsar only.

In the early seventies, in Mokalsar, water jars were made with the clay from Mokalsar, the ones in Pachpadra were made with the clay from Pachpadra, the ones from the Jodhpur region were made with the clay from Rohat.

The same sources of clay in Mokalsar and Pachpadra still prevail. However, as time goes by there are more and more villages ordering salty clay from Mokalsar. Orders come from villages as far as Ramasani or Banjara $(180 \mathrm{~km})$. On the contrary, Rohat clay is less and less exploited as a source given local problems of access. Initially, it was located on a piece of land allotted by the government to whom potters were giving 200 Rs ${ }^{1}$ per trailer. For 4 years (2009) the land has been "closed", due to villagers complaining that the land was dotted with hollows in which the cows kept falling. The potters had then to turn to private landowners to get their clay. As a result, clay has become very expensive (one trailer of clay costs 1500 Rs instead of $200 \mathrm{Rs}$ ). Moreover, the clay is not as good as before: it contains a lot of stones which is time consuming when pounding and sieving it. As a consequence, potters are progressively giving up the Rohat clay and buy more and more the Mokalsar variety, even though distances can be considerable.

\section{Discussion: the conditions for the diffusion of morphofunctional types}

In brief, Mokalsar jars are considered the best water jars. They out-compete all the red clay jars. They are distributed over a huge area: from Rajasthan - districts of Jodhpur, Barmer, Nagaur, Jalor, Pali, Ajmer districts - , down to Gujarat - from Ahmedabad down to Surat. Their production has increased progressively between 1988 and 1998. Since 2000, they are the predominant production within the Jodhpur region. They are manufactured by both Muslim and Hindu potters. From the consumer's point of view, their success lies in their cooling properties. From the producer's point of view, their widespread adoption comes from the economic benefits to be gained. Their demand has been relayed by shopkeepers who interacted with middlemen or potters, asking the latter either to make them or telling them how to make them ("we want this type of pot"; "go to Mokalsar to find the raw material").

This case study shows firstly that as long as the Prajapat and the Moila potters of the Jodhpur area were not in competition there was no diffusion of any of the morpho-stylistic types manufactured by each group. More precisely, up to the seventies, the Moila did not manufacture any water jars even though they were selling their vessels under a market economy to both rural and urban populations and could thus have copied the Pachpadra jars to increase their revenues. In their own words, there was no question of making water jars as long as the Hindu potters were making them. This phenomenon of non-borrowing morphological types, even in a market economy, is not an exception. This has been observed in other places in India (Roux, 2013) or in Africa, as, for example, in Ethiopia where recently a French team ${ }^{2}$ could observe two ethnic groups producing different morpho-functional types of ceramics, selling them on the same markets and not borrowing from each other even though a few types of vessel within each group sell better than others and could be copied by each group to improve their revenues. The recurrence of the non-borrowing phenomenon over time and space is what makes cultural boundaries.

In the Jodhpur area, the adoption of the Mokalsar jar by all the producers has been content-dependent in the sense that it was motivated by the profit it generates. It took place in a geographical area bringing together different communities of potters in competition through a market economy.

${ }^{1}$ In 2013, $100 \mathrm{Rs}=1.23 € .{ }^{2}$ This team is led by Jessie Cauliez (CNRS) and the field work is conducted within the framework of the project DIFFCERAM. 
Fig. 5. High observability of the white water jars. Above: white water jars sold in Jodhpur city. Below: white water jar in a stall; water is available for consumers.

Transmission was through one to one, or a one to multiple individuals. Demonstrations mainly concerned the preparation of the clay, but also the paddling process. On the contrary, there was no demonstration within the Hindu community whose ties are looser given exogamy between the clans constituting the subcastes. Technical guidance within the Moila community has contributed still more to the widespread diffusion of the Mokalsar jar in that the Moila community has expanded to the detriment of the Hindu.

To sum-up, our case study shows that the adoption of the same morpho-functional type of vessel by two communities which used to distinguish themselves by their range of vessels occurred thanks to different modes of transmission. The traits which have diffused are highly visible and testable. They have been copied through two modes of transmission: transmission without and with interaction between potters.

(1) Transmission without interaction between potters. It allows copying mechanisms to be implemented by circumventing the social filter which maintains differentiated production between groups of potters. It involves imitation of objects and verbal guidance by individuals who are involved in their distribution. It has been observed at the inter-group level. The result is the spreading of a same type of vessel over a large area as recorded elsewhere with exogenous vessel shapes introduced on markets by outsiders [examples in Niger (Corniquet, 2011)] or in Turkey (Kalentzidou, 2000). The importance of the visibility of vessel shapes in their diffusion has already been underlined in ethnoarchaeology (Gosselain, 2000). We insist here on the possibility of morphological traits being diffused between different social groups, independently of their geographical proximity and their social networks, thanks to indirect transmission. We insist also on the efficiency of verbal guidance by non potters for diffusion of a clay paste recipe since it is not often evoked, numerous case studies showing adoption of new clay recipes mainly as a result of interactions between potters, or potters and customers (Gelbert, 2003; Gosselain, 2010a, 2008; Gosselain and Livingstone Smith, 2005).

(2) Transmission with interaction between potters. It involves technical guidance. In our case study, it had a minor role in the diffusion process of the water jar. It has been observed at the intra-group level only. The importance of the social networks in the homogenization process of technical practices has been underlined and demonstrated now for some time (Arnold, 2000; Dobres, 2000; Gosselain, 2010a; Stark et al., 2008). This process can take place within a same social group, but can also include individuals from different social groups in the course of time, blurring then social borders and signaling communities of practice rather than social groups (Gosselain, 2010a, 2010b; Gosselain, 2008; Livingstone Smith, 2000). In the Indian case, the homogenization of the clay recipe has benefited from direct contacts between potters, but at the intra-group level only. At the inter-group level, it has been neither the result of common practice (Hindu and Muslim potters do not meet on clay sources), nor the result of mutual contacts (the Hindu and Muslim potters did not exchange their recipe through direct contact) despite existing social contacts (Hindu and Muslim potters do visit each other and entertain friendly relationships) and geographical proximity.

In order now to make use of these observations for interpreting archaeological data, the question is what context triggers indirect transmission, the main manner through which the water jar became standardized over a large area. Our case study shows that the replica of the model has been determined by the intention to make a product that sells well. This intention, expressed through the content dependent copying mechanism, was initiated by the collapse of the jajmani system and the consequent rupture of the economic equilibrium between the two communities of potters.

Other intentions may prevail with the standardization of morpho-functional traits across social boundaries as an outcome. Indeed, these intentions as well as the factors initiating them are necessarily ad hoc, historically dependent. However, whatever the nature of the intentions of the artisans and the factors responsible for them, the fact is that when standardized morpho-functional types replaces a diversified production and therefore "erases" previous cultural boundaries, it signals that the "rule" according to which affiliation and differentiation create and maintain such boundaries (Brubaker and Cooper, 2000; Lave and Wenger, 1991) has been transgressed. The meaning of this transgression depends on the context of production. By reference to our case study, in a context where ceramic diversified production is economically complementary, such a transgression signals that major socio-economic changes have taken place.

In archaeology interpreting the standardization of ceramic assemblages in terms of major socio-economic changes will imply recognizing that standardized production succeeded to a diversified production in the hands of different groups of potters, which can be established with the help of a technological analysis (Roux, 2011). In our ethnographic case, the two communities, the Prajapat and the Moila, could have been identified on the basis of their tools (different paddles) and their firing structures.

Lastly, standardization due to cultural diffusion ought to be distinguished from standardization due to demic diffusion. The latter implies recognizing the spreading of one technical tradition to the detriment of previous ones (Roux, in press).

\section{Conclusion}

The objective of this paper was to provide regularities for understanding standardization of morpho-functional traits within geographical areas where ceramic assemblages used to be diversified. For this purpose, we examined the diffusion of a granite tempered water jar in the Jodhpur region. This region is inhabited by two communities of potters who before were producing distinct ranges of ceramic vessels. An analysis of the transmission mechanisms explaining how the same model of water jars came to be manufactured by all the artisans shows that there are different modes of transmission which are social context dependent. Imitation of objects and verbal guidance promoted diffusion beyond social borders without interaction between potters. On the contrary, technical guidance requiring interactions between potters promoted diffusion at the intra-group level only. These transmission mechanisms apply to traits which are highly visible and testable. They have been triggered by major changes in the socio-economic organization of the ceramic production. Such changes appear necessary for standardization to spread within previously technologically fragmented areas. In return, applied to archaeology, standardization may signal major socio-economic changes.

On a more general level, and to conclude, let us here insist on the fact that empirical data show well that in order to understand cultural change, not only copying mechanisms should be taken into account, but also the modes of transmission to implement them as well as the social context in which they are triggered. As we have shown, copying successful models can be achieved with different modes of transmission, each of them operating under different social conditions. This implies that in archaeology understanding the process of standardization of morpho-functional traits should entail not only acknowledging their nature and the copying mechanisms (e.g. Mesoudi and O'Brien, 2008), but also considering the socio-economic context into which the transmission mechanisms took place. In this perspective, the small-scale observations here reported do not serve to understand directly large-scale historical dynamics (as proposed by Mesoudi and O'Brien, 2009; Mesoudi, 2007, 2009). They aim at highlighting the a-temporal, anthropological regularities which specify the socio-economic context in which transmission mechanisms are triggered and that we need for explaining the diversity of historical trajectories. 


\section{Acknowledgments}

This study has been funded by the ANR (Agence Nationale de la Recherche) within the framework of the program CULT

(Metamorphosis of societies - «Emergences and evolution of cultures and cultural phenomena»), project DIFFCERAM (Dynamics of spreading of ceramic techniques and style: actualist comparative data and agent-based modeling). In Jodhpur, the support of the Rupayan Sansthan was invaluable. I want to thank here Kuldeep Kothari warmly for his help in sorting out all the logistic problems as well as Meet Kaur Gulati and Lakshman Diwakar for their assistance in the field. I would like also to thank all the potters for their availability and their unfailing kindness. The photographs are from the author. The layout of the illustrations is from Carole Duval (CNRS, UMR 7055).

\section{References}

Arnold, D.E., 2000. Does the standardization of ceramic pastes really mean specialization? J. Archaeol. Method Theory 7 (4), $333-376$.

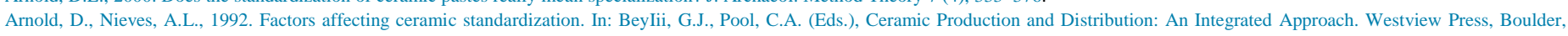
Colorado, pp. 113-214.

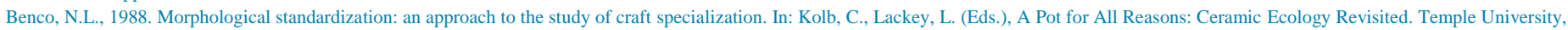
Philadelphia, pp. 57-72.

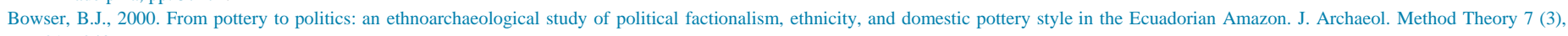
219-248.

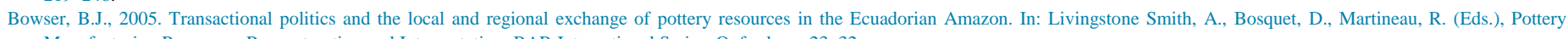
Manufacturing Processes: Reconstruction and Interpretation. BAR International Series, Oxford, pp. 23-32.

Boyd, R., Richerson, P.J., 1985. Culture and the Evolutionary Process. University of Chicago Press, Chicago.

Brubaker, R., Cooper, F., 2000. Beyond "Identity". Theory Soc. 29, 1-47.

Corniquet, C., 2011. Cadres de pratiques et circulation des connaissances chez les potières de l'Arewa (Niger). Cahiers d'études Africaines 1, 87-114.

Costin, C.L., 2001. Craft production systems. In: Feinman, G.M., Price, T.D. (Eds.), Archaeology at the Millennium. Springer, US, pp. $273-327$.

Costin, C.L., Hagstrum, M.B., 1995. Standardization, labor investment, skill, and the organization of ceramic production in late prehispanic highland Peru. Am. Antiquity 60 (4), 619-639.

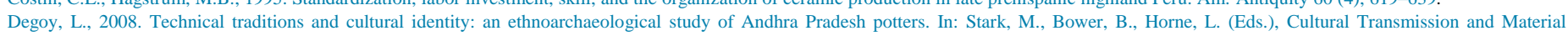
Culture. Breaking down Boundaries. The University of Arizona Press, Tucson, pp. 199-222.

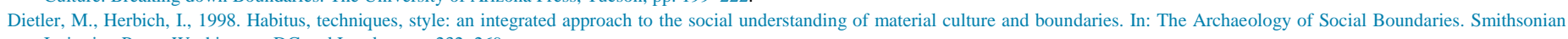
Insitution Press, Washington, DC and London, pp. 232-269.

Dobres, M.A., 2000. Technology and Social Agency. Blackwell Publishers, Oxford. Gallay, A., 2011. Pour une ethnoarchéologie théorique. Editions Errance, Paris.

Gelbert, A., 2003. Traditions céramiques et emprunts techniques dans la vallée du fleuve Sénégal. Editions de la Maison des sciences de l'homme, Editions Epistèmes, Paris.

Glatz, C. (Ed.), 2015. Plain Pottery Traditions in the Ancient Near East. Left Coast Press, Walnut Creek, California, in press.

Gosselain, O.P., 2000. Materializing identities: an African perspective. J. Archaeol. Method Theory 7, 187-217.

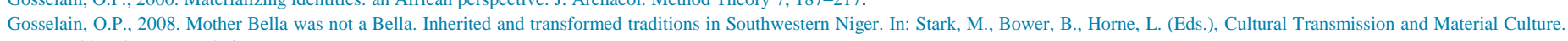
Breaking down Boundaries.

Arizona University Press, Tucson, pp. 150-177.

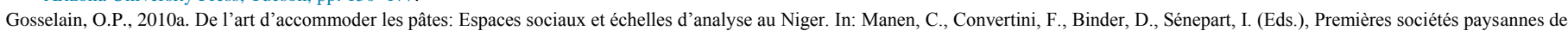
la Méditerranée orientale, Mémoire de la Société Préhistorique Française Société Préhistorique Française, Paris, pp. $249-263$.

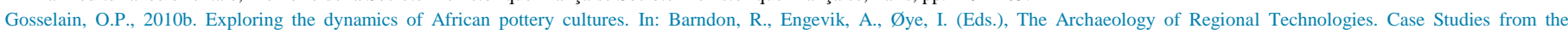
Palaeolithic to the Age of the Vikings. The Edwin Mellen Press, Lampeter, pp. 193-224.

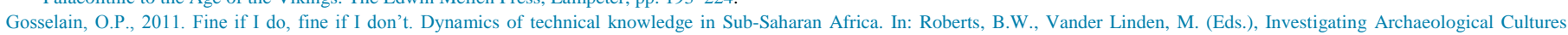
Material Culture, Variability, and Transmission. Springer Science+Business Media, New York, London, pp. 211-227.

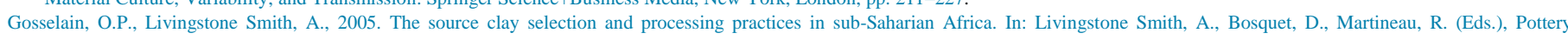
Manufacturing Processes: Reconstruction and Interpretation. BAR International Series, Oxford, pp. 33-48.

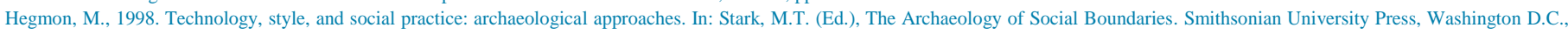
pp. 264-279.

Henrich, J., Boyd, R., 1998. The evolution of conformist transmission and the emergence of between-group differences. Evol. Human Behav. 19, 215-242.

Henrich, J., McElreath, R., 2003. The evolution of cultural evolution. Evol. Anthropol. 12, 132-135.

Hodder, I., 1985. Boundaries as strategies: an ethnoarchaeological study. In: The Archaeology of Frontiers and Boundaries. Academic Press, New York.

Kalentzidou, O., 2000. Discontinuing traditions: using historically informed ethnoarcheaology in the study of Evros ceramics. J. Archaeol. Method Theory 7 (3), $165-186$.

Kramer, C., 1997. Pottery in Rajasthan. Ethnoarchaeology of two Indian Cities. Smithsonian Institution Press, Washington and London.

Kvamme, K.L., Stark, M.T., Longacre, W.A., 1996. Alternative procedures for assessing standardization in ceramic assemblages. Am. Antiquity 61 (1), $116-126$.

Lave, J., Wenger, E., 1991. Situated Learning: Legitimate Peripheral Participation. Cambridge University Press, Cambridge.

Lemonnier, P., 1993. Technological Choices: Transformation in Material Cultures since the Neolithic. Routledge, London and New York.

Lemonnier, P., 2004. Mythiques chaînes opératoires. Tech. Culture, 2-14.

Livingstone Smith, A., 2000. Processing clay for pottery in northern Cameroon: social and technical requirements. Archaeometry 42 (1), $21-42$.

London, G.A., 1991. Standardization and variation in the work of craft specialists. In: Ceramic Ethnoarchaeology. The University of Arizona Press, Tucson, pp. $182-204$.

Longacre, W.A., 1999. Standardization and specialization: What's the link? In: Pottery and People: A Dynamic Interaction. University of Utah Press, Salt Lake City, pp. 44-58.

McElreath, R., Boyd, R., Richerson, P.J., 2003. Shared norms and the evolution of ethnic markers. Curr. Anthropol. 44, 122-130.

Mesoudi, A., 2007. Using the methods of social psychology to study cultural evolution. J. Social Evol. Cultural Psychol. 1, 35-58.

Mesoudi, A., 2009. How cultural evolutionary theory can inform social psychology and vice versa. Psychol. Rev. 116, 929.

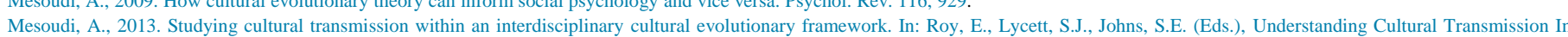
Anthropology: A Critical Synthesis, Methodology and History in Anthropology. Berghahn Books, Oxford, pp. 131- 147.

Mesoudi, A., O’Brien, M.J., 2008. The cultural transmission of Great Basin projectilepoint technology I: an experimental simulation. Am. Antiquity, 3-28.

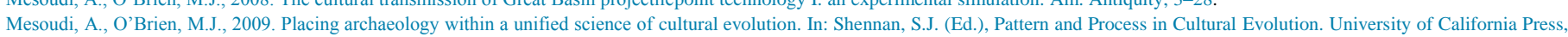
Berkeley and Los Angeles, California, pp. 21-32.

O'Brien, M.J., Bentley, R.A., 2011. Stimulated variation and cascades: two processes in the evolution of complex technological systems. J. Archaeol. Method Theory $18,309-337$.

Rice, P., 1991. Specialization, standardization and diversity: a retrospective. In: The Ceramic Legacy of Anna O. Shepard. University Press of Colorado, Boulder, Colorado, pp. 257-279.

Richerson, P.J., Boyd, R., 2005. Not by Genes Alone. How Culture Transformed Human Evolution. The University of Chicago Press, Chicago and London.

Rogers, E.M., 2003. Diffusion of Innovations, fifth ed. Free Press, New York.

Roux, V., 2003. Ceramic standardization and intensity of production: quantifying degrees of specialization. Am. Antiquity 68, 768-782

Roux, V., 2007. Ethnoarchaeology: a non historical science of reference necessary for interpreting the past. J. Archaeol. Method Theory 14, 153-178.

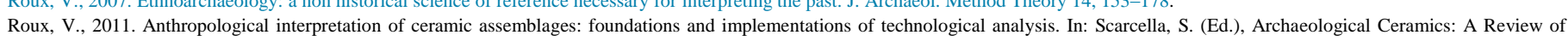
Current Research, B.A.R International Series, pp. 80-88.

Roux, V., 2013. Spreading of innovative technical traits and cumulative technical evolution: continuity or discontinuity? J. Archaeol. Method Theory $20,312-330$.

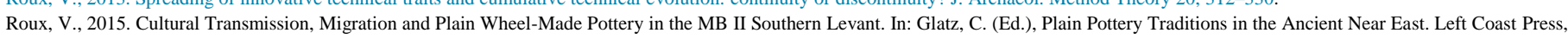
Walnut Creek, California (in press).

Shennan, S.J., 2002. Genes, Memes and Human History: Darwinian Archaeology and Cultural Evolution. Thames \& Hudson, London.

Shennan, S., 2008. Evolution in archaeology. Annu. Rev. Anthropol. 37, 75-91. 


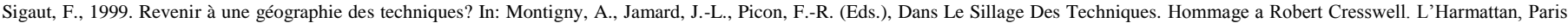
pp. 513-531.

Stark, M.T., 1995. Economic intensification and ceramic specialization in the Philippines: a view from Kalinga. Res. Econom. Anthropol. 16, 179-226.

Stark, M.T. (Ed.), 1998. The Archaeology of Social Boundaries. Smithsonian Series in Archaeological Inquiry. Smithsonian Institution Press, Washington, WA, London.

Stark, M.T., Bowser, B.J., Horne, L. (Eds.), 2008. Cultural Transmission and Material Culture. Breaking down Boundaries. The University Arizona Press, Tucson. 